Acta vet. scand. 1989, 30, 229-230.

Brıef Communicatıon

\title{
Radionuclide Uptake in Experimentally Induced Meniscal Lesions in Rabbit Knees
}

Internal derangements in the human knee joint caused by meniscal lesions affecting joint function are known to have influence on local radionuclide uptake (Nicholas \& Holder 1980, Mooar et al. 1987). To elucidate the joint reaction to minor meniscal lesions, not interfering with knee joint function, a model involving the avascular central part of the medial meniscus was used. Lesions in this area are known not to heal spontaneously (Heatley 1980, Veth et al 1983).

A medical knee joint arthrotomy was performed in both knees in 8 full-grown rabbits under Hypnorm $^{\mathrm{TH}} \quad$ (fentanyl-fluanisone) anesthesia.

On the right side a stainless steel spatula was induced under the cranial part of the medial meniscus to protect the underlying cartilage. A 3-4 mm long longitudinally penetrating cut was made in the meniscus in the zone between the central and middle third between the enterior and middle portion of the meniscus. After removal of the spatula, the joint was closed in layers with absorbable sutures.

On the left knee, a medial arthrotomy of similar extension was performed and the spatula was placed between the medial meniscus and the underlying cartilage of the tibia. At this side the meniscus was not incised. After removal of the spatula, the joint was closed as the right knee. Within a week after the operation the 8 rabbits moved normally. 8-10 weeks after the operation each of the rabbits was given an i.v. dose of $185 \mathrm{MBq}$ of 99m TC-methylene diphosphonate. Between 2 and $3 \mathrm{~h}$ after the injection, the rabbits were anesthetized, and examined with a gammacamera (Maxi Camera, General Electric). Areas of interest were placed around the knee joints for scintimetric registration of the bilateral joint activity. An equally sixed area for counting of background was placed over the soft tissue in the surroundings of the joints. At least 10,000 counts were sampled in each region giving a counting error of maximally $1 \%$ on each registration. The activity in each knee joint was after background correction calculated as counts per sec.

Increased isotope uptake in the right knee was seen in all rabbits. The results of the scintimetric measurements (Table 1) showed significantly higher count rates at the right side $\mathrm{p} \leq 0.01$ (Wilcoxon test for paired differences).

Two weeks after bone imaging the right medial menisci were examined during another medial arthrotomy. None of the lesions showed any signs of healing or local reaction.

Our results demonstrate, that even minor undisplaceable lesions in the avascular part of the meniscus significantly affects the hemodynamics of the joint. However, the method used in this study prevents us from determination of the relative contribution of the enhanced activity from the subchondral bone and from synovia.

The findings further raise the question as to whether the changes observed are reversible 
Table 1. Scintımetric results given as counts/sec in the knee regions.

\begin{tabular}{lrrrrrrrr}
\hline Rabbit number & 1 & 2 & 3 & 4 & 5 & 6 & 7 & 8 \\
\hline $\begin{array}{l}\text { Knee with meniscal lesion } \\
\text { (right knee) }\end{array}$ & 115 & 160 & 90 & 65 & 115 & 110 & 125 & 135 \\
$\begin{array}{l}\text { Knee without meniscal lesion } \\
\text { (left knee) }\end{array}$ & 80 & 15 & 15 & 9 & 75 & 50 & 80 & 75 \\
\hline
\end{tabular}

(Reimann et al. 1982), stationary or progressive. Studies to clarify this are in progress.

\section{Acknowledgements}

This study was made possible by grants from The Danish Sports Research Council.

A Hede,

Department of Orthopaedics, Rigshospitalet, University of Copenhagen.

$J$ Madsen and E Svalastoga,

Department of Small Animal Diseases and

Clinical Practice, Royal Veternnary and

Agricultural University, Copenhagen.

$J$ Bülow,

Department of Clinical Physiology and Nuclear

Medicine, Bispebjerg Hospital, Copenhagen.

\section{References}

Heatley $F W$ The meniscus - can it be repaired? J. Bone Joint Surg. 1980, 62-B, 397-402.

Mooar P, Gregg J, Jacobstein J Radionucleotide imaging in internal derangements of the knee. Amer. J. Sports Med. 1987, 15, 132-137.

Nicholas $J A$, Holder $L E$ Bone Imaging in Orthopaedic Medıcıne. ProClinıcal, New York 1980.

Reimann I, Christensen SB, Diemer NH Observations of reversibility of glucosaminoglucan depletion in artıcular cartilage. Clin. Orthop. 1982, 168, 258-264.

Veth RPH, Den Heeten GJ, Jansen HWB, Nielsen HKL Repair of the meniscus. Clin. Orthop. 1983, 175, 258-262.

(Recelved February 13, 1989, accepted May 19, 1989)

Reprints may be requested from: Eiliv Svalastoga, Department of Small Animal Diseases and Clinical Practice, Royal Veterınary and Agrıcultural University, Bülowsvej 13, DK-1870 Frederıksberg C, Copenhagen, Denmark. 